\title{
The Local Wisdom Values of Custom Society in Cisitu Lebak Banten in Effort to Build Nation Character
}

\author{
Ethnographic Studies in Custom Communities of Cisitu Lebak Banten
}

\author{
Yudha Dana Prahara, Kokom Komalasari and Iim Siti Masyitoh \\ Civic Education Department, School of Postgraduate Studies \\ Universitas Pendidikan Indonesia \\ Bandung, Indonesia \\ yd.prahara@student.upi.edu
}

\begin{abstract}
Sundanese culture has certain characteristic that distinguish with the other culture, it is known as religious society. In the Sundanese culture the magical balance (in the science of customary law called religious magic) is maintained by performing traditional ceremonies, while the social balance of the Sundanese is done by mutual cooperation. One of Sundanese culture that still hold out is the tradition of custom ceremony "Seren Taun" in Custom Community of Cisitu Lebak Banten. This ritual is one example of wisdom local from the custom part, within there are many kinds activities that content with positive value such as: Ngarasul, Pongokan, Ngalaukan and Balik Taun. The traditions content with positive nation's characters. This article discusses about The Local Wisdom Values of Custom Society in Cisitu Lebak Banten In Effort to build the character of nation. This problem attracts our attention to do the scientific research. The research methodology that we used is qualitative method by ethnographic studies. The research has been done found that the Series of Process Serentaun Ritual Custom Ceremony have many kind community activities which content of the local wisdom values that harmonize with the values of Indonesian national's characters especially Five Major Characters in implementation of Reinforcement Character Education that has been planned by our government in The Movement of Mental Revolution, they are: Religious, nationalist, Independent, Mutual Cooperation and Integrity.
\end{abstract}

Keywords—local wisdom; culture; nation's character

\section{INTRODUCTION}

Positive values of the nation such as nationalism, religious values, human values, integrity, brotherhood, mutual cooperation and exemplary, now they begin to be eroded in the society cultural environment. The entry of Globalization era at least affects the attitudes and paradigms of the society now days such as the emergence of consumptive cultural modernism, egoism of individual and group till to the point of apprehensive and this is the practice to allow any ways.

It signifies the cultural existence and the cultural values owned by the Indonesian people until now are not optimal, in an effort to build the character of society, in this case the character of citizens, even every time we pay attention various actions of Social Pathology (social disease society) that effect to the destruction of a nation, they are the decline in behavior of courtesy, honesty, togetherness and mutual cooperation among members of the community. In accordance to the statement above, it is suspected that the source of various bad behaviors in society is the emergence of socio-cultural animosity [1].

Based on the case above there are 10 (ten) signs of human behavior that indicate the destruction of a nation, they are: (1) The Increasing of violence among teenagers; (2) Cultural dishonesty; (3) Increasing disrespect to parents, teachers and leaders; (4) The influence of peer groups on acts of violence; (5) increasing suspicion and hatred; (6) The use of deteriorating language; (7) Declining work ethic; (8) Decreasing the sense of responsibility of individuals and citizens; (9) Raising selfdestructive behavior; (10) Increasingly the blurred of moral guidance [2].

Ten signs of that behavior are apprehensive to bring social impacts that cause a collision of value, to a certain condition of community will experience a crisis of identity, it is not impossible if it continues, it will potentially to split our nation. In a confusing situation they looking for reference to solve various problems, there is a tendency for some people to return to the centuries-old local wisdom in overcoming the various problems of life.

The loving of local culture is one manifestation from a high sense of belonging to the local wisdom value in a region. Local wisdom is part of cultural construction. Haba says that: "Local wisdom refers to varieties of cultural richness that grow and thrive in a society, it is known, trusted and recognized as important elements that capable in strengthening social cohesion among citizens" [3].

According to Haba Local wisdom as part of the cultural construction, it shows that the values which grow and develop in a society is used as a guide and guidance are doing in every social activity. To know about a local wisdom in a region, it is necessary to understand their cultural values in their region, 
such as some indigenous cultures that are manifested in various forms of activities such as traditional ceremonies performed by hereditary.

One of the Sundanese culture that still survive is traditional ceremonial ritual Serentaun on custom communities Cisitu in district Cibeber Lebak Banten. This ritual is one example of local wisdom from the matters of custom, in addition to the values, norms, ethics, beliefs, laws and other special rules contained in this traditional society.

The Serentaun Ceremonial Ritual Process is one of the many kinds activities that become the style of The Custom community of Cisitu, the various activities of custom community of Cisitu have at least local wisdom values that are in harmony with the Indonesian character's values, especially in implementing the 5 (Five) the main values of the character of the Nation in the program Reinforcement of Character Education (KDP), they are Religious, Nationalist, Independence, Mutual cooperation and Integrity.

The character building of nation through the wisdom of local culture is needed. The character building of the nation can be taken by applying the values of local wisdom as one way to build the character of nation. It is the foundation for the strength and sturdy of Indonesia's national values in achieving of the expected goals. Nation and character building are two majors that the Indonesian nation needs to be able to maintain its existence [1].

Based on the description above, so the problem to be raised in this article is "How does the Values of local wisdom in the Custom Community of Cisitu Lebak Banten in an effort to build the character of the nation?".

\section{THEORITICAL}

\section{A. Culture}

Etymologically, the word "culture" comes from cultural is forwarded by Koentjaraningrat: The word "cultural" is derived from Sanskrit, as "buddhayah", it is the plural form of buddhi meaning "mind". The foreign word "culture "derived from the Latin's word "colere" (i.e. "processing" or "working", and especially related to the processing of the soil or farming), has the same meaning as "culture", and then it evolves into "all efforts and human actions to cultivate the land changing nature " [4].

Thus, Culture is an idea derived from the work, taste, and human creation by learning as a guide for human behavior in community life. Cultural is created by human, and instead that human is created by culture so both of them cannot be separated by any ways.

Furthermore, the form of culture is a system, it is delivered by Koentjaraningrat, "He recommends to distinguish the form of culture as a system from idea and concept of culture as a series of pattern of human actions and activities" [4]. Therefore, the form of culture is divided into three cultural phenomena, they are (1) ideas, (2) activities, and (3) artifacts. [5][4].
In addition to the three cultural forms above, mentions seven cultural elements: (1) Language, (2) Knowledge system (3) Social organization (4) System of living equipment and technology, (5)) Livelihood system, (6) Religious system, (7) Art [4].

\section{B. The Values of Local Wisdom}

The Definition of local wisdom is defined as an intelligence possessed by a certain ethnic group, obtained through the experience of the ethnic that struggle with their environment. Local wisdom is united with the character of society, because its existence is always implemented and preserved, in a certain condition even highly regarded [6].

While Suhartini defines local wisdom as a heritage of ancestors related with the values of life. The values of life are united not only in the form of religion, but also in culture and customs. When a community adapts to its environment, they develop a good wisdom, they are knowledge or ideas, tools, combined with norms and custom, and cultural values of environment to fulfill their living needs [7].

\section{Nation Character Building}

Character is a pattern of attitudes that it attaches to a person, the characters attach to each individual, which is reflected in the patterns of behavior in daily life [8]. A person's character is influenced by environmental factors (nurture) and gift factors (nature).

While Zubaedi defines that character as a subjective assessment to a person's personality related with personality attributes that can or cannot be accepted by society [9]. Character is a whole nature's character and disposition that dominated stably. It is defining in whole psychic behavior. It makes types in the way of thinking and acting.

The efforts in the nation character building are important to develop because it is parallel with the Consideration of Presidential Regulation No.87 of 2017 on Reinforcement of Character Education point (b) it declares that in order to realize a cultured nation through reinforcement of religious values, honesty, tolerant, disciplined, hardworking, creative, independent, democratic, curiosity, spirit of nationality, love of the homeland, appreciate achievement, communicative, love peace, love reading, caring environment, social care and responsible, they need reinforcement of character education.

\section{METHOD}

This research uses a qualitative research approach with the goal is that the researchers more freely in reviewing and analyzing various phenomena are encountered in the sphere comprehensively. Then the method used is Ethnography method because Ethnographic Research learns about cultural events, presenting the life vision of the study subject and it is a model of social sciences research using the foundation of phenomenology philosophy ".

According to Denzin, ethnographic research describes how to think, how to live, how to behave as a "social settings study". Ethnographic research is a study of intact cultural groups and natural in a period of time [10]. Others researcher 
states that Ethnographic research process is flexible and contextual, it develops as a response to the reality of life that encountered in the sphere in the ontological perspective nature of the phenomena or social reality [11] [12] [13].

Determination of informants in this study uses the purpose sampling technique. Meanwhile, for data collection using interview technique, observation, documentation study and literature study. Then the process of data analysis in this study, such as data reduction, data presentation and conclusion or verification [14] [15].

The location of this research is located in two villages, hey are Kujangsari Village and Situmulya Village, Cibeber District, Lebak Regency of Banten Province, because the Cisitu custom communities are living in the both locations above.

\section{RESUlt AND DisCUSSION}

Based on the result of research revealed that the Series of Serentaun Ritual Custom Ceremony Process in custom community of Cisitu Lebak Banten has variety of activities that contain the local wisdom value in harmony with the values of the main characters of Indonesia, they are Religious, Nationalism, Independence, mutual cooperate and Integrity.

The results of interviews with Chief Adat (Kasepuhan) and Personage of Indigenous People and observation result of custom community activities of Cisitu shows that in Serentaun traditional ceremony has values of local wisdom such as: first Ngarasul procession or gathering activity for praying to God Almighty as a form of their gratitude for a given of agricultural product, this as a form of Religious Value. As the identification expressed by Komalasari and Saripudin, "The value of religious character reflects the belief to God Almighty that manifested in action of doing in religion and beliefs, respect for religious differences, high tolerance of the implementation another religion and beliefs, living in harmony and peace with other religion and believers" [8]. Based on this procession Ngarasul regarded as one of the activities that reflect the faith to God the Almighty.

The second value of local wisdom is Pongokan it is Prohibition of activity in taking the harvest in any way before the ritual of Serentaun Custom Ceremony. The term of Pongokan is a form of strong obligation community to customary norms as part of the Integrity values. The identification expressed by Komalasari and Saripudin, the value of integrity character is based on effort to establish their self as a person who is always believable in words, actions and work, committed and faithfulness to humanity and morals (moral integrity) [8]. Integrity character includes the attitude of responsibility as a citizen, it is caused to involve in social life, through the consistency of actions and words based on the truth. The value of Pongokan is considered as an attitude of indigenous peoples' responsibility in their social life, with obey all established rules, so the customary community considers that the consistently actions is a special truth.

Third Local Wisdom Value is Ngalukan, Ngalaukan term is a tradition of the community to give part their crops and livestock to the Chief Adat (Kasepuhan) consciously and without duress to be processed and consumed by all citizens at the peak of Serentaun Custom Ceremony event, the activity is a manifestation of Independence and Mutual cooperation value among the citizens. As the identification expressed by Komalasari and Saripudin, that the value of Independence and Mutual cooperation characters are an attitude and behavior that independent to the other and uses all the energy, thought, time to realize hope, dreams and aspirations, and reflect acts of appreciation to the spirit of cooperation and help each other to solve their problems, keep in touch and friendship, giving help to people in need [8]. Ngalaukan tradition is considered by indigenous peoples as a form of cooperation spirit among the people in order to help each other among fellow citizens in realizing the agenda of Serentaun tradition.

The fourth Local Wisdom is Balik Taun, Balik Taun tradition is a tradition to return and re-assemble or back to hometown for indigenous people who are stayed outside the city or abroad before the Serentaun ceremony. This tradition as a form of their responsibility in maintaining good relationship in their family and their custom communities in general. Besides that, in this tradition indigenous people must report their activities outside the city for one year to the customary head. This tradition held as a manifestation of growing the unity and integrity of society in maintaining the tradition as part of the Nationalism. As the identification expressed by Komalasari and Saripudin, the character value of a nationalist is a way of thinking, behaving and doing that shows high loyalty, awareness and respect for language, the physical environment, social and cultural, economic and political of their nation, it is placed above self-interest and group [8]. Tradition of Balik Taun is considered by indigenous peoples as a manifestation of high appreciation to the physical environment and socio-culture of the nation as a reflection of the sense belonging to the nation's culture.

Based on the expression above, the application of local wisdom values in the process of performing ceremonial Serentaun as an effort in the character building of the nation can be done by constructing the value into the form of daily activities of society, this is suitable with the theory of social construction that views humans as the creator of reality that has the ability to engage in objectivity that has manifested their self in available human activity, both to himself and to others around them as a part of collective life [16]. Because of human are placed as the creators of reality, the knowledge of people about the reality that appears in their life is the result of social construction.

Thus, the tradition of Ngarasul, Pongokan, Ngalaukan and Balik Taun as a form of religious characteristic values, integrity, independence, mutual cooperate and nationalism, they inherent from the ancestral value that always absolute preserved as an effort to build the character of the nation, it is expected, in accordance with forwarded by Sapriya, that The effort to build the character of a citizen is essentially a process of inheriting the values, ideas and national objectives that contained in the state constitution and the message of the state founders [17]. 


\section{CONCLUSION}

The Custom Ceremony Serentaun in the community of Cisitu Lebak Banten is one of the cultures and traditions of the Sundanese people who still survive in the middle of globalization era. In the process of implementation in this tradition, there are various activities that contain the values of Local Wisdom that can build the character of the nation. The values are first Procession Ngarasul as a form of Religious Value or the value of devotion to God Almighty, Second Pongokan as a form of strong obedient of communities to customary norms as part of the value of Integrity, Third Ngalaukan, is a form of value Independence and mutual cooperation among custom communities. Fourth Tradition of Balik Taun, as a manifestation of the growing unity and integrity of society in maintaining the tradition as part of the Nationalism attitude. By applying the local wisdom values, the custom societies of Cisitu can internalize the value and construct it into the form of daily activities, this is considered as an effort to build the character of the nation that is expected.

\section{REFERENCES}

[1] Budimansyah. D, Penguatan Pendidikan Kewarganegaraan untuk Membangun Karakter Bangsa. Bandung: Widya Aksara Press, 2010.

[2] Lickona. T, Educating For Character How Our Schools Can Teach Respect and Responsibility. New York: Bantam Books, 1992.

[3] Haba. J, Revitalisasi Kearifan Lokal: Studi Resolusi Konflik di Kalimantan Barat, Maluku, dan Poso. Jakarta: ICIP dan European Commission, 2007.

[4] Koentjaraningrat, Pengantar Ilmu Antropologi. Jakarta: Rineka Cipta, 2009.
[5] Honigman J.J, Culture and Personality. New York: Harper \& Brothers, 1959.

[6] Rahyono. F.X, Kearifan Budaya dalam Kata. Jakarta: Wedatama Widya Sastra, 2009.

[7] Suhartini, Prosiding Seminar Nasional Penelitian, Pendidikan dan penerapan MIPA. Yogyakarta, 2009, [Internet]. Retrivied: http://www.searchdocument.com/pdf/1/KajianKearifan-LokalMasyarakat-dalam-Pengelolaan-Sumberdaya-AlamdanLingkungan.html, 17 April 2014.

[8] Komalasari. K. and Saripudin. D, Pendidikan Karakter: Konsep dan Aplikasi Living Values Education. Bandung : Refika Aditama, 2017.

[9] Zubaedi, Pendidikan Karakter:Konsep dan Aplikasinya Dalam Lembaga Pendidikan. Jakarta: Kencana, 2011.

[10] Denzin and Lincoln, Handbook of Qualitative Research. London: Sage Publication, 2000.

[11] Grant. L and Fine. G.A, "Sociology unleashed: Creative directions in classical ethnography". In M.D. Le Compte, W.L. Millroy and J. Preissle (Eds.), The Handboks of Qualitative research in Education. New York: Academic Press, pp. 405-446, 1992.

[12] Spradley. J.P, The Participation Observation. New York: Reinhart \& Winston, 1980.

[13] Creswell. J.W, Research Design: Pendekatan Kualitatif, Kuantitatif, dan Mixed. Yogyakarta: Pustaka Pelajar, 2010.

[14] Miles. M and Huberman. A.M, Analisis Data Kualitatif. Jakarta: UIPress, 2007.

[15] Sugiyono, Metode Penelitian Pendidikan (Pendekatan Kuantitatif, Pendekatan Kualitatif dan R\&D). Bandung: ALFABETA, 2009.

[16] Berger. P.L and Luckmann. T, Tafsir Sosial atas Kenyataan. Risalah tentang Sosiologi Pengetahuan. Jakarta: LP3ES, 1990.

[17] Sapriya. "Peran Pendidikan Kewarganegaraan dalam Membangun Karakter Warga Negara," Jurnal Sekolah Dasar Tahun 16 Nomor I, Mei 2007. 